\title{
Roles of Fas and Fas ligand during mammary gland remodeling
}

\author{
Joon Song, ${ }^{1}$ Eva Sapi, ${ }^{1}$ Wendi Brown, ${ }^{1}$ Jon Nilsen, ${ }^{1}$ Karrie Tartaro, ${ }^{2}$ \\ Barry M. Kacinski, ${ }^{1,2}$ Joseph Craft, ${ }^{3}$ Frederick Naftolin, ${ }^{1}$ and Gil Mor ${ }^{1}$ \\ ${ }^{1}$ Department of Obstetrics and Gynecology, \\ ${ }^{2}$ Department of Therapeutic Radiology, and \\ ${ }^{3}$ Department of Internal Medicine, Yale University School of Medicine, New Haven, Connecticut, USA
}

Address correspondence to: Gil Mor, Department of Obstetrics and Gynecology, Yale University, School of Medicine, 333 Cedar Street FMB 202, New Haven, Connecticut 06520, USA.

Phone: (203) 785-6294; Fax: (203) 785-4883; E-mail: Gil.Mor@yale.edu.

Received for publication May 23, 2000, and accepted in revised form October 13, 2000.

\begin{abstract}
Mammary involution is associated with degeneration of the alveolar structure and programmed cell death of mammary epithelial cells. In this study, we evaluated the expression of Fas and Fas ligand (FasL) in the mammary gland tissue and their possible role in the induction of apoptosis of mammary cells. FasL-positive cells were observed in normal mammary epithelium from pregnant and lactating mice, but not in nonpregnant/virgin mouse mammary tissue. Fas expression was observed in epithelial and stromal cells in nonpregnant mice but was absent during pregnancy. At day 1 after weaning, high levels of both Fas and FasL proteins and caspase 3 were observed and coincided with the appearance of apoptotic cells in ducts and glands. During the same period, no apoptotic cells were found in the Fas-deficient (MRL/lpr) and FasL-deficient $(\mathrm{C} 3 \mathrm{H} / g l d)$ mice. Increase in Fas and FasL protein was demonstrated in human (MCF10A) and mouse (HC-11) mammary epithelial cells after incubation in hormone-deprived media, before apoptosis was detected. These results suggest that the Fas-FasL interaction plays an important role in the normal remodeling of mammary tissue. Furthermore, this autocrine induction of apoptosis may prevent accumulation of cells with mutations and subsequent neoplastic development. Failure of the Fas/FasL signal could contribute to tumor development.
\end{abstract}

J. Clin. Invest. 106:1209-1220 (2000).

\section{Introduction}

Breast cancer is a major cause of death in women, and its occurrence has particular relevance to women's health worldwide. The fact that the mammary gland is the source of the most frequent malignancy in the female population and the knowledge that mammary tumorigenesis is influenced by the reproductive history of the individual emphasizes the importance of a better understanding of how pregnancy and lactation influences breast development and differentiation (1-3). Pregnancy, lactation, and the postlactational period entail a remodeling of the mammary gland mediated by programmed cell death (PCD) (apoptosis) necessary for successive lactation cycles. The apoptosis associated with breast involution has been implicated in resistance to tumorigenesis while inappropriate survival of the mammary secretory epithelial cells increases susceptibility to tumor development (4-6). Accordingly, conditions that limit proliferation or cause cell death could reduce the risk for breast cancer in humans (1-3).

Apoptosis is a process regulated by many genes and factors, including the Fas/Fas ligand (FasL) system (7-9). Fas (Apo-1/CD95) is a 45-kDa cell-surface receptor of the TNF/nerve growth factor receptor family whose signal transduction pathway mediates apopto- sis of Fas-bearing cells after binding with FasL $(10,11)$. Although the Fas/FasL system was originally described in the context of lymphocyte-mediated apoptosis, new data have shown that Fas and FasL are widely expressed and function in many tissues outside the immune system. Under these circumstances, the expression of FasL in cells of the testis (12), the anterior chamber of the eye (13), the trophoblast (14-16), and the brain (17) may confer protection against immune responses by locally inducing the death of activated Fas-bearing immune cells that infiltrate into these tissues. As a result, FasL has been proposed to obviate immune suppression by cancer cells, allowing cancer or other abnormal cells to "escape" from immune surveillance by the induction of apoptosis of activated Fas-bearing immune cells (18-21). We reported recently the presence of FasL in hyperplastic ducts and breast cancer cells, but not in normal glandular epithelium, suggesting that the Fas/FasL system might play an important role in the development of breast carcinoma (18). These observations have lead us to study the expression of FasL in normal mammary epithelial cells during pregnancy and involution to evaluate whether FasL expression correlates with the stage of mammary epithelial cell differentiation (18). 
Terminal differentiation of the mammary gland normally takes place only during pregnancy and lactation when there is a cycle of lobulo-alveolar and ductal division followed by a period of lactation, after which cells of the secretory mammary epithelium and ducts become committed to apoptotic cell death. Gestational and lactogenic hormones regulate this pathway of differentiation. Changes in the hormonal environment at the end of lactation trigger the apoptotic signal required for "breast remodeling" $(22,23)$ perhaps also through the Fas-FasL system.

To test the role of the Fas/FasL system in breast remodeling we studied the expression of Fas and FasL in the mammary tissue of normal BALB/c, MRL, C3H, as well as in Fas-deficient (MRL/lpr) and FasL-deficient $(\mathrm{C} 3 \mathrm{H} / \mathrm{gld})$ mice through the different stages of their lactogenic differentiation. We also evaluated the presence of apoptosis during involution in wild-type MRL and $\mathrm{C} 3 \mathrm{H}$ mice and compared it with the natural knockout $\mathrm{MRL} / \mathrm{lpr}$ and $\mathrm{C} 3 \mathrm{H} / \mathrm{gld}$ mice. To confirm our in vivo data we also studied caspase activation and apoptosis in normal human and mouse mammary epithelial cells. In this report we describe how Fas and FasL expression is altered during pregnancy, lactation, and postlactational period, and show how these changes are hormonally regulated. We also demonstrated the role of the Fas/FasL system as a mediator of apoptosis of mammary epithelial cells during the first stage of mammary gland involution.

\section{Methods}

Cells and culture condition. Cells were cultured in DMEM/F-12 media containing antibiotics and antimycotics $(1 \% \mathrm{vol} / \mathrm{vol})$ and proper serum at $37^{\circ} \mathrm{C}$ in a humidified chamber $\left(5 \% \mathrm{CO}_{2}\right.$ in air). Cells were passed by standard methods of trypsinization, plated in tissue culture dishes for RNA and protein extraction, and allowed to replicate $80 \%$ confluence. The standard media for culture of $\mathrm{HC}-11$ contained dexamethasone $(1 \mu \mathrm{M})$, insulin $(5 \mu \mathrm{g} / \mathrm{ml})$, prolactin $(5 \mu \mathrm{g} / \mathrm{ml})$, and FBS (10\% vol/vol). The media for culture of MCF-10A contained EGF $(20 \mathrm{ng} / \mathrm{ml})$, insulin $(1 \mathrm{ng} / \mathrm{ml})$, hydrocortisone $(500 \mathrm{ng} / \mathrm{ml})$, cholera toxin $(100 \mathrm{ng} / \mathrm{ml})$, and horse serum $(5 \% \mathrm{vol} / \mathrm{vol})$. After cell cultures were continued with standard media for 72 hours, starvation media (SM) excluding serum and hormones, and phenol red was initiated for each planned schedule.

DMEM/F-12, FBS, and horse serum were purchased from Life Technologies (Grand Island, New York, USA). HC-11 cells were a gift from Nancy Hynes, and MCF$10 \mathrm{~A}$ cells were purchased from the American Type Culture Collection (Rockville, Maryland, USA). All other chemicals, unless otherwise specified, were obtained from Sigma Chemical Co. (St. Louis, Missouri, USA).

Animal experiment specimens from mice. All studies involving animals were approved by Yale Institutional Review Boards for Animal Care. Cycling female (60-90 days old) BALB/c mice, MRL/MpJ (MRL), and the Fasdeficient MRL/lpr $(l p r)$ mice came from an in-house colony and were originally obtained from The Jackson Laboratories (Bar Harbor, Maine, USA). The MRL/lpr mouse is a natural mutation of the MRL/MpJ mouse, therefore its genetic background is $100 \% \mathrm{MRL} / \mathrm{MpJ}$ (24). $\mathrm{C} 3 \mathrm{H} / \mathrm{He}(\mathrm{C} 3 \mathrm{H})$ and $\mathrm{C} 3 \mathrm{H} /$ gld $/$ gld $($ gld $)$ were purchased from The Jackson Laboratories, and their genetic background is $100 \% \mathrm{C} 3 \mathrm{H} / \mathrm{HeJ}(n=10)(25)$. Animals were housed under controlled temperature $\left(22^{\circ} \mathrm{C}\right)$, humidity, and light (14 hours light, 10 hours dark). After deep ether anesthesia and excision, each mammary gland specimen was frozen in liquid nitrogen for RNA and protein extraction or fixed in 4\% freshly made paraformaldehyde, then paraffin-embedded for immunohistochemistry. Tissue blocks were stored at room temperature until $5-\mu \mathrm{m}$ sections were cut and mounted. Mice were sacrificed after the removal of the tissue.

Preparation of total RNA and protein samples. Total RNA and proteins were prepared from frozen mouse mammary gland tissue, frozen human breast tissue, and cultured breast cell lines using TRIzol reagent (Life Technologies Inc., Gaithersburg, Maryland, USA) according to the manufacturer's instructions. We used the TRIzol protocol to extract RNA and protein from the same cells. This method allowed us to study the same samples at both the mRNA and protein level.

RT-PCR. Details of the characterization for the RT-PCR were described previously $(26,27)$. In short, reverse transcription was performed using the RT-PCR kit from Pharmacia BioTech (Piscataway, New Jersey, USA) according to the manufacturer's directions. The cDNA synthesis was performed with $\mathrm{pd}(\mathrm{N})_{6} 0.2 \mu \mathrm{g}$ and $5 \mu \mathrm{g}$ total RNA. The primers used for amplification of FasL have been described previously (28) and have the following sequence: for humans, upstream, 5'-ATAGGATCCATGTTTCTGCTCTTCCACCTACAGAAGGA-3' and downstream, 5'ATAGAATTCTGACCAAGAGAGAGCTCAGATACGTTGAC 3 ; for mice, upstream, 5'-AAGCTTCAGCTCTTCCACCTG-3' and downstream, 5' ATGAATTCCTGGTGCCCATG-3'. Each PCR cycle for human FasL consisted of denaturation at $94^{\circ} \mathrm{C}$ for 30 seconds, annealing at $52^{\circ} \mathrm{C}$ for 30 seconds, and elongation at $72^{\circ} \mathrm{C}$ for 1 minute, for a total of 35 cycles. Each PCR cycle for mice FasL consisted of denaturation at $94^{\circ} \mathrm{C}$ for 1 minute, annealing at $60^{\circ} \mathrm{C}$ for $30 \mathrm{sec}-$ onds, and elongation at $72^{\circ} \mathrm{C}$ for 30 seconds, for a total of 30 cycles. The primer used for amplification of Fas has the following sequence: for humans, upstream, 5'-AAGGAGTACACAGACAAAGCCC-3' and downstream, 5'-AAGAAGAAGACAAAGCCACCC-3'; for mice, upstream, 5'-GAGAATTGCTGAAGACATGACAATCC-3' and down stream, 5'-GTAGTTTTCACTCCAGACATTGTCC-3'. Each PCR cycle for human Fas consisted of denaturation at $94^{\circ} \mathrm{C}$ for 30 seconds, annealing at $57^{\circ} \mathrm{C}$ for 30 seconds, and elongation at $72^{\circ} \mathrm{C}$ for 30 seconds, for a total of 30 cycles. Each PCR cycle for mouse Fas consisted of denaturation at $94^{\circ} \mathrm{C}$ for 1 minute, annealing at $53^{\circ} \mathrm{C}$ for $30 \mathrm{sec}-$ onds, and elongation at $72^{\circ} \mathrm{C}$ for 30 seconds, for a total of 35 cycles. The PCR products were analyzed in Tris-EDTA (TAE) 1-2\% agarose gel with ethidium bromide. 
The Fas and FasL signals were measured by a densitometer and standardized against the actin signal using a digital imaging and analysis system (AlphaEase; Alpha Innotech Corporation; San Leandro, California, USA). The linearity of the system was determined using serial dilution of CDNA, and the regulation of dilution factor on amplified cDNA was linear $(y=2881.125 x-$ 785.75 ) and the correlation coefficient was $r=0.994$, as described previously $(26,27)$.

Western blot analysis. Proteins were separated by SDSPAGE using $10 \%$ polyacrylamide gels and transferred to nitrocellulose membrane. Immunoblotting was performed after blocking nonspecific binding by the membranes with $5 \%$ powdered milk. The blots were incubated first with the primary Ab for FasL (mAb clone 33, 1:1000 dilution; Transduction Laboratory, Lexington, Kentucky, USA) or primary Ab for Fas (polyclonal Ab M-20 at 1:500 dilution; Santa Cruz Biotechnology Inc., Santa Cruz, California, USA) for 1 hour. After washing, the membranes were incubated with the secondary Ab, peroxidase-labeled horse anti-mouse or goat anti-rabbit gamma globulin (Vector Laboratories, Burlingame, California, USA), for another hour. Finally, the blots were developed with TMB Peroxidase substrate kit (Vector). The specificity of the anti-FasL mAb clone 33 used in this study was evaluated by Western blot analysis, comparing it with two different clones, the polyclonal Ab N-20 from Santa Cruz Biotechnology Inc. and clone NOK-1 from PharMingen (San Diego, California, USA). (See refs. 26, 27 for details.)

Immunohistocytochemistry for Fas and FasL. Detection of Fas and FasL expression was performed using a rabbit polyclonal IgG containing anti-human FasL or mouse monoclonal IgG containing anti-human Fas (N-20 or B-10, respectively; Santa Cruz Biotechnology Inc.). Deparaffinized and rehydrated $5-\mu \mathrm{m}$ sections were blocked for endogenous peroxidase activity with $0.3 \%$ $\mathrm{H}_{2} \mathrm{O}_{2}$ in methanol, washed in PBS, and preincubated with $10 \%$ normal goat or horse serum in PBS/5\% BSA for 1 hour to block nonspecific binding of the Ab's. The primary $\mathrm{Ab}$ (1:200 dilution for FasL and 1:50 dilution for Fas) in dilution buffer (PBS plus 5\% BSA and 0.1\% saponin) was applied. Slides were then incubated for 12 hours overnight at $4^{\circ} \mathrm{C}$ in a humidified chamber. After washing, sections were incubated for 1 hour with a biotinylated horse anti-mouse $\mathrm{Ab}$ or biotinylated goat anti-rabbit $\mathrm{Ab}$ (Vector Laboratories) for Fas and FasL, respectively. Detection of the secondary Ab was amplified using the $\mathrm{ABC}$ system according to the manufacturer's instructions (Santa Cruz Biotechnology Inc.). Color development was done with the 3'3-diaminobenzidine HCL (DAB) substrate (Immunopure metalenhanced DAB substrate kit; Pierce Chemical Co., Rockford, Illinois, USA), and sections were counterstained with hematoxylin. In the negative control samples, the primary Ab was omitted or preabsorbed with recombinant Fas or FasL, as described previously (17). DNA fragmentation assay (JAM assay). Cell death of mammary epithelial cells resulting from the elimina- tion of hormones from the culture was quantified by measurement of target-cell DNA fragmentation using the JAM assay (29). Adherent mammary epithelial cells (MCF-10A or HC-11 cells) were seeded into the wells of a flat, microwell, 96-well Falcon plates at a cell number appropriate to give the required confluence. Target-cell DNA was labeled by prior incubation with $10 \mathrm{Ci} / \mathrm{ml}$ of $\left[{ }^{3} \mathrm{H}\right]$-thymidine at $37^{\circ} \mathrm{C}$ for 24 hours. Labeled cells were washed and cultured in $200 \mu \mathrm{l} /$ well of hormonedeprived media. After culture at $37^{\circ} \mathrm{C}$ for $6-24$ hours, the cells were removed from the wells and filtrated onto glass fiber filters using an automatic 96-well filtration unit. The cells were then lysed with hypotonic buffer, and their DNA was washed through the filter by four washes with double-distilled water. The radioactivity of intact chromosomal DNA retained on each filter was measured by liquid-scintillation counting. Specific cell death was calculated using the following equation (29): percentage of specific cell death $=(S-E / S) \times 100$, where $E$ (experimental) is counts per minute of retained (complete) mammary epithelial cell DNA in the hormonedeprived media and $S$ (spontaneous) is counts per minute of retained DNA in hormone-containing media.

In situ localization of apoptotic cells: annexin $V$. Staining of apoptotic cells was done using the ApoAlert annexin V system (CLONTECH Laboratories, Palo Alto, California, USA), according to the instructions of the manufacturer. In short, cells were cultured in four-well chamber slides. After treatment, cells were incubated for 10 minutes with annexin V-FITC, followed by three washings with PBS, then fixed with $4 \%$ paraformaldehyde. For counterstaining, cells were incubated with DAPI (4,6,-diamidino-2-phelylindole). Positive cells were detected by fluorescent microscopy (Carl Zeiss Inc., Jena, Germany).

In situ 3 ' end labeling of DNA for cell death detection. The presence in mammary tissue sections of single-strand DNA breaks indicating apoptosis was assessed using the terminal deoxynucleotidyl transferase-mediated dUTP nick-end labeling (TUNEL) technique (In Situ Cell Death Detection Kit, Fluorescent; Boehringer Mannheim Biochemicals Inc., Indianapolis, Indiana, USA), according to the manufacturer's instructions. Briefly, after deparaffinization and rehydration, slides were incubated with proteinase $\mathrm{K}(20 \mathrm{mg} / \mathrm{ml}$ in $10 \mathrm{mM}$ Tris/HCL, pH 7.4) for 30 minutes at $37^{\circ} \mathrm{C}$. Samples were then treated with terminal deoxynucleotidyl transferase enzyme and fluorescein-labeled nucleotides for 60 minutes at $37^{\circ} \mathrm{C}$ in the dark. In the negative control sections the enzyme was omitted. An alkaline phosphatase-anti-fluorescein $\mathrm{Ab}$ was added and a nitroblue tetrazolium alkaline phosphatase kit (Vector) was used for color development.

Fas-induced apoptosis. The effect of SM on Fas sensitivity was evaluated by incubating mammary epithelial cells with an anti-human Fas mAb (R\&D Systems, Minneapolis, Minnesota, USA). One-hundred fifty microliters of $5 \times 10^{3}-1 \times 10^{4}$ cells in DMEM-F12 with $5 \%$ horse serum were seeded in 96-well flat-bottomed 
microplates (Becton-Dickinson, Franklin Lakes, New Jersey, USA) and incubated for 48 hours. Then the medium was exchanged, and the cells were incubated with various doses of the mouse monoclonal IgG antiFas $\mathrm{Ab}$ in $200 \mu \mathrm{l}$ of medium with or without serum. Normal mouse IgG Ab (Santa Cruz Biotechnology Inc.) was used as control. Cells were also treated with antiFasL (100 ng/ml NOK-1 mAb; PharMingen) or a mouse IgG1 isotype-matched control mAb $(100 \mathrm{ng} / \mathrm{ml}$; PharMingen) at the time of plating. Twenty microliters of 3-(4,5-dimethylthiazol-2-yl)-2,5-diphenyltetrazolium bromide (MTT; Sigma Chemical Co.) dye was added into each well 4 hours before the end of the incubation. The supernatant was removed and $100 \mu \mathrm{l}$ of acidified isopropyl alcohol was added to solubilize the reactive crystals. Absorbency was measured at $540 \mathrm{~nm}$ by an automatic microplate reader (Model 550; BioRad Laboratories Inc., Hercules, California, USA). Background consisted of medium only and no cells. Percentage of the absorbency relative to the control was calculated, and the survival graph was drawn. Each assay was performed at least three times in triplicate.

Statistical analysis. Data were analyzed for statistical significance by using Student's $t$ test. All experiments were repeated two or three times with similar results.

\section{Results}

Fas/FasL mRNA expression in the mouse mammary gland. Terminal differentiation of the mammary gland normally takes place only during pregnancy and lactation. Gestational and lactogenic hormones regulate this pathway of differentiation. Changes in the hormonal environment at the end of lactation trigger the apoptotic signal required for "breast remodeling". We tested the hypothesis that the Fas/FasL system could mediate apoptotic signals during tissue remodeling by studying the expression of Fas and FasL in mice mammary tissue. Studying mice, we analyzed Fas and FasL expression at the mRNA and protein level. RT-PCR was performed on samples ( $n=3$ /group) obtained from nonpregnant virgin mice during pregnancy days 15 and 19, after 10 days of lactation, and days 1, 2, 4, and 12 after weaning. The intensity of the signal was analyzed by densitometry as described in Methods and plotted as a bar in Figure 1. Fas mRNA was clearly detectable in all tissues studied (Figure 1). In contrast, FasL mRNA was absent in nonpregnant, virginal mice (Figure 1, lane 1), began to appear by day 15, and was greatest on day 19 of pregnancy (Figure 1, lanes 2 and 3 ). During lactation and the first day of weaning, FasL mRNA was also present in high levels (Figure 1, lanes 4 and 5 ), but decreased dramatically by postlactational days 4 and 12 (Figure 1, lanes 6-8)

Western blot analysis for Fas, FasL, and caspase 3 expression in the mouse mammary gland. To compare the expression of Fas and FasL mRNA with protein expression we performed Western blots on protein preparations from the same samples we employed for mRNA analysis. The intensity of the staining was analyzed by densitometry as described above. As shown in Figure 2, Fas and FasL protein expression differed strikingly from their patterns of mRNA expression. Mammary glands from virgin mice express high protein levels of Fas, but not FasL, protein (Figure 2, lane 1). However, during pregnancy and lactation, Fas protein expression was suppressed (Figure 2, lanes 2-4), while FasL was expressed in high amounts compared with the nonpregnant mouse mammary gland (Figure 2, lanes 2-4).

Removal of the litters, which constitute the primary factor for mammary gland involution, had a profound effect on Fas expression; 24 hours after the removal of the litters, Fas protein level increased dramatically (Figure 2, lane 5). Quantification of the signal indicated a statistically significant increase $(P<0.001)$ of Fas protein levels on days $1,2,4$, and 8 of involution compared with the protein levels detected during pregnancy (Figure 2, lanes $5,6,7$, and 8 , respectively). FasL protein levels remained high during the first two days of involution and were significantly reduced from days 4 to 12 after weaning $(P<0.05)$ (Figure 2, lanes 5, 6, 7, and 8, respectively). Similarly, the active form of caspase 3 was detected by Western blot analysis during mammary gland remodeling. Thus, high concentration of the active form of caspase 3 was mainly detected during the first 4 days of involution (Figure 3, lanes 3-6), decreasing afterward (Figure 3, lanes 7 and 8). On the other hand, the active form of caspase 3 was not expressed in the mammary tissue from nonpregnant/virgin mice (Figure 3, lane 1).

Localization of FasL and Fas expression in the normal mouse mammary gland. To determine which cells expressed Fas and FasL, we performed immunohistochemistry on

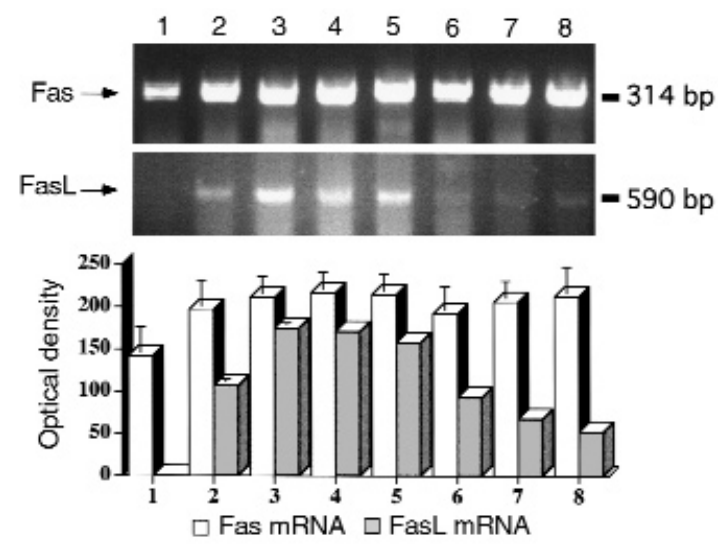

Figure 1

Expression of Fas/FasL mRNA in mouse mammary tissue. RT-PCR for Fas/FasL was performed with total RNA extracted from BALB/c mice during pregnancy, lactation, and involution. FasL mRNA was expressed during pregnancy, lactation, and early involution, but not in breast tissue from virgin mice. Fas mRNA was present in all the tissues evaluated. The intensity of the signal was analyzed using a digital imaging analysis system (AlphaEase). Bars represent the average \pm SD from three independent experiments. The figure of the gel is a representative experiment of the three experiments. Lane 1, virgin; lane 2, day 15 of pregnancy; lane 3, day 19 of pregnancy; lane 4, day 10 of lactation; lane 5, day 1 after weaning (AW); lane 6, day 2 AW; lane 7, day 4 AW; lane 8, day 12 AW. 

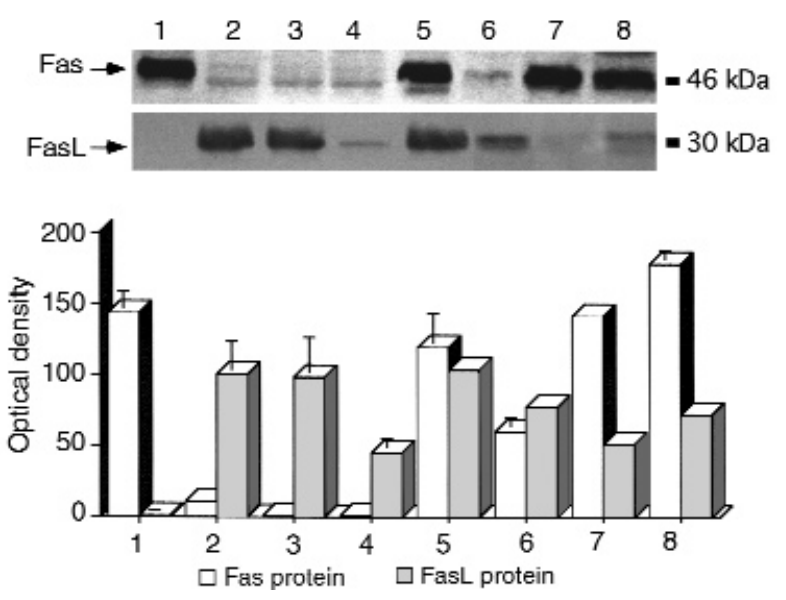

\section{Figure 2}

Expression of Fas/FasL protein in mouse mammary tissue. Western blot analysis for Fas and FasL was performed with protein samples obtained from the same samples described in Figure 1. Fas expression is found in breasts from virgin mice but is not expressed during pregnancy and lactation. High levels of Fas protein appear 1 day after weaning. FasL is expressed during pregnancy, lactation, and involution, but not in the virgin mouse. The intensity of the signal was analyzed using a digital imaging analysis system. Bars represent the average \pm SD from three independent experiments. The figure of the immunoblot is a representative experiment of the three experiments. Lane 1, virgin; lane 2, day 15 of pregnancy; lane 3, day 19 of pregnancy; lane 4, day 10 of lactation; lane 5 , day $1 \mathrm{AW}$; lane 6 , day 2 AW; lane 7, day 4 AW; lane 8, day 12 AW.

paraffin sections of the mammary gland from normal mice during pregnancy, lactation, and weaning. Sections were stained with a polyclonal $\mathrm{Ab}$ for FasL (clone N-20; Santa Cruz Biotechnology Inc.) and for Fas using the mAb B-10 (Santa Cruz Biotechnology Inc.). Mammary gland tissues were collected from virgin mice and during different days of pregnancy (as described in Methods), lactation, and involution. Mammary gland samples from virgin mice were immune negative for FasL (Figure 4a), but positive for Fas (Figure 5a). However, at days 15 and 19 of pregnancy abundant FasLpositive immunoreactive cells were found in the glandular epithelium (Figure 4b). The number and intensity of positive immunoreactivity for FasL increased significantly as pregnancy progressed (from day 5 to day 19, data not shown). Immunoreactivity for Fas was almost absent, with the exception of a few scattered positive stromal cells with the cytology of macrophages and leukocytes (Figure 5b, and data not shown). After delivery and during lactation, few Fas-positive glandular epithelial cells were found, while FasL immunoreactivity was present in almost all of the glandular epithelium, including ducts (data not shown).

Localization of FasL and Fas expression during mammary gland involution. Postlactational involution of the mammary gland during weaning is characterized by cell death of portions of the mammary epithelium. To determine how Fas and FasL expression is related to mammary gland involution we stained paraffin sections from mouse mammary glands obtained consecutive days after weaning. The number of glandular epithelial cells expressing FasL and Fas increased dramatically between day 1 and 2 after weaning (Figure 4, $\mathrm{c}$ and d; Figure 5, c and d). By day 4, the tissue was characterized by the presence of mainly ducts and clusters of epithelial chordae surrounded by adipocytes. Although FasL was still present, it was expressed in fewer cells than on previous days (Figure 4f).

Presence of apoptotic cells in the mammary epithelium of normal mice, but not in the Fas-deficient lpr mice. To determine if the expression of Fas and FasL is related to the apoptosis of the mammary epithelium characteristic during involution, we performed histological analysis by using the TUNEL assay on paraffin sections derived from mammary glands at days 1, 2, 4, and 12 of involution in normal BALB/c mice. Similarly, we compared the presence of apoptotic cells in the involuting mammary gland of MRL mice, the Fas-deficient MRL/lpr mice, as well as of $\mathrm{C} 3 \mathrm{H}$ and $\mathrm{C} 3 \mathrm{H} / \mathrm{gld} /$ gld (FasL-deficient) mice. When we analyzed DNA fragmentation in mammary glands from $\mathrm{MRL} / \mathrm{lpr}$ or $\mathrm{C} 3 \mathrm{H} / g l d / g l d$ mice, no apoptotic cells were detected during the first 3 days of involution (Figure 6, c and e). However, apoptotic cells were present at day 4 after weaning in the MRL/lpr mice (Figure $6 \mathrm{~d}$ ) and in the $\mathrm{C} 3 \mathrm{H} / g l d / g l d$ mice (Figure 6f). In contrast, DNA fragmentation (shown as blue nuclei) was present at day 1 of involution in MRL (Figure $6 \mathrm{a}$ ) and $\mathrm{C} 3 \mathrm{H}$ mice and increased to a substantial number at day 2 of involution, reaching a relative maximum at day 4 after weaning (Figure 6b).

In vitro hormonal regulation of Fas and FasL expression in mammary epithelial cells. To establish an in vitro model to study the role of the Fas/FasL system in mammary epithelial cell-mediated apoptosis, we performed studies using either the normal mouse epithelial cell line HC-11 or the normal human epithelial MCF-10A cells (data not shown).

Effect of hormone withdrawal on Fas and FasL expression by normal mouse HC-11 mammary epithelial cells. To study the hormonal involvement in Fas/FasL expression during involution of the mouse mammary gland, we attempted to reproduce in vitro conditions resembling

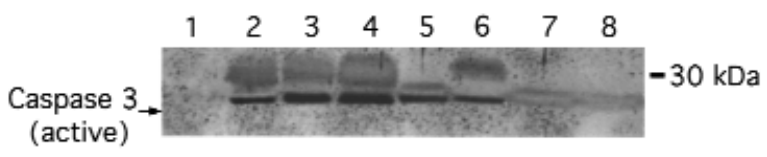

\section{Figure 3}

Expression of caspase 3 in mouse mammary tissue. Western blot analysis for caspase 3 was performed with protein samples obtained as described in Figure 1. Increase in the expression of the active form of caspase 3 was detected 24 hours after weaning; expression remained high during days 2 and 4 of involution, decreasing afterward. Lane 1, virgin; lane 2, lactation 10 days; lane 3, day 1 AW; lane 4, day 2 AW; lane 5, day 3 AW; lane 6, day 4 AW; lane 7, day 8 AW; lane 8, day 12 AW. 
normal involution after weaning. The mouse mammary glandular epithelial cell line $\mathrm{HC}-11$ was cultured in DMEM-F12 with 10\% FCS and containing dexamethasone $(1 \mu \mathrm{M})$, insulin $(5 \mu \mathrm{g} / \mathrm{ml})$, and prolactin $(5 \mu \mathrm{g} / \mathrm{ml})$ to induce lactogenic differentiation as described previously (30). We used a JAM or a MTT assay to evaluate the effect of hormone and serum withdrawal on Fas and FasL expression. Both methods gave similar results. As shown in Figure 7, HC-11 cells grown in normal conditions express only very low levels of Fas protein (Figure 7a, lane 1) and do not express FasL protein (Figure $7 b$, lane 1). By 1 hour after removal of the serum and hormones from the media (SM), there was a fourfold increase in Fas protein levels, and they remained high for up to 24 hours (Figure 7a, lanes 2-5). Interestingly, FasL protein expression increased only after 2 hours of incubation in SM and reached its highest level measured after 24 hours (Figure 7b, lanes 3-5).

Effect of SM treatment on caspase 3 expression. Fas/FasL-induced apoptosis is mediated by the activation of a proteolytic system involving proteases called caspases. The activation of caspase 3 is an important component of this cascade. To further confirm the involvement of the Fas/FasL system in the induction of apoptosis of mammary epithelial cells, we studied caspase 3 expression in $\mathrm{HC}-11$ cells after removal of serum and hormones. As shown in Figure 7c, HC-11 cells maintained in normal conditions express only the inactive form of caspase 3 (Figure 7c, lane 1); incubation in SM induced the activation of caspase 3 in $\mathrm{HC}-11$ cells after 1 hour (corresponding to Fas and FasL expression). As apoptosis progressed, the amount of the inactive form of caspase 3 decreased (Figure 7c, lanes 2-5).

Correlation between Fas/FasL expression and apoptosis in mammary epithelial cells. To compare the in vitro effect of hormonal deprivation on mammary epithelial cells' Fas and FasL expression and activation of caspase 3 with apoptosis, we performed annexin V and JAM assays. Cells were treated with SM as described above followed by incubation with FITC-labeled annexin V. Cells were then observed under a fluorescent microscope using 4,6diamidino-2-phenylindole (DIP) as marker for the presence of cells in the culture. As shown in Figure 8, numerous annexin $\mathrm{V}$-positive cells were present after 24 hours (Figure $8 \mathrm{~d}$ ) and 48 hours (Figure $8 \mathrm{f}$ ) in SM, but not in the control group (Figure $8 \mathrm{~b}$ ). To quantify the number
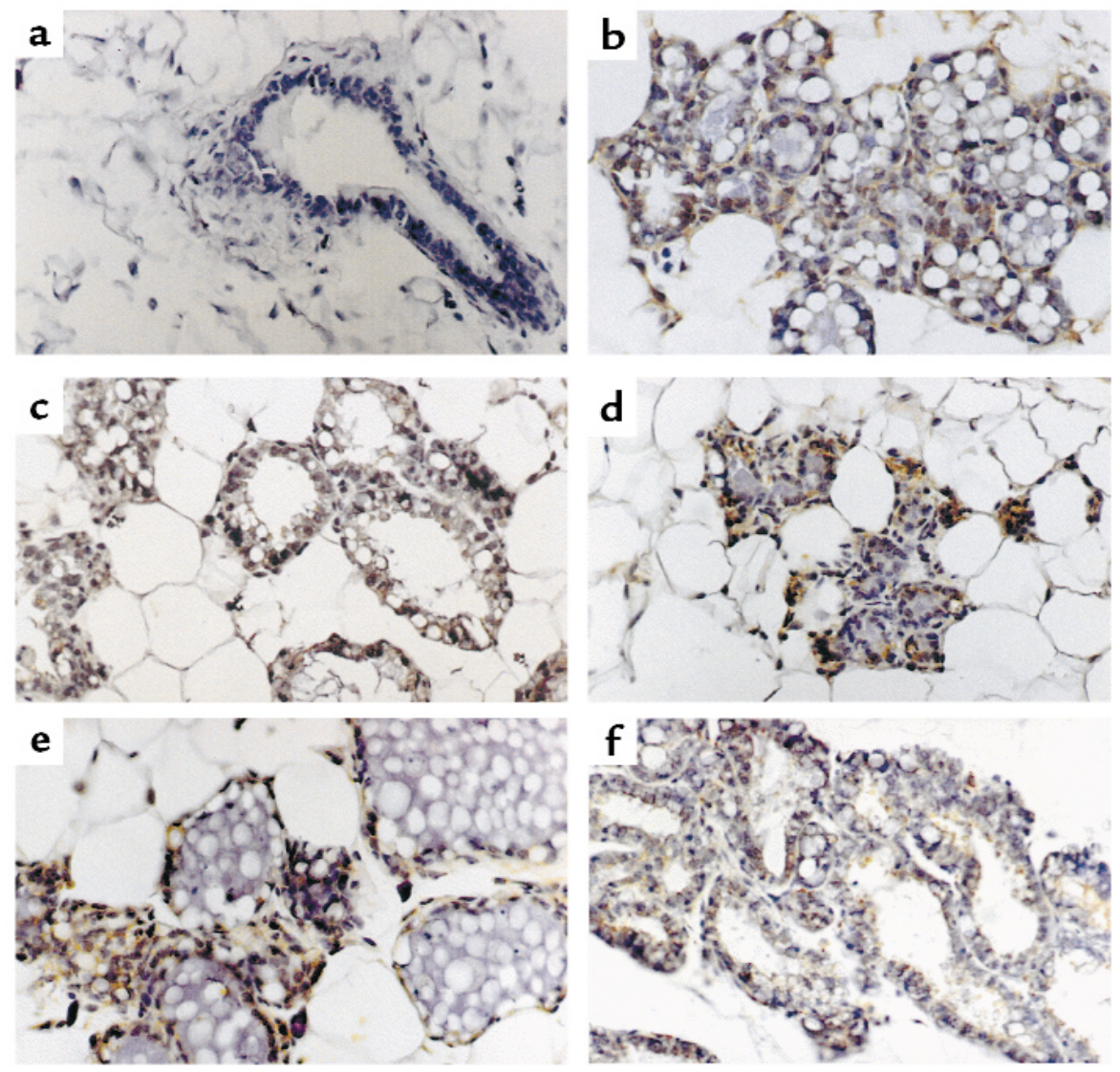

\section{Figure 4}

Localization of FasL expression in mouse mammary tissue during pregnancy, lactation, and involution. Paraffin sections of normal breast tissue were stained with anti-mouse FasL Ab. (a) Virgin mouse breast, showing immune negative for FasL. (b) Day 15 of pregnancy, abundant positive FasL immune reactivity was shown in the glands. (c) Day 1 of involution, Fas L immunoreactivity is present in glandular epithelial cells surrounding milk accumulation. (d) Day 2 of involution, the number of FasL-expressing cells increased. (e) Day 3 of involution. (f) Day 5 of involution, characterized by presence of ducts and epithelial chordae surrounded by adipocytes with localization of FasL in a few cells. $\times 400$. 
of apoptotic cells that were the result of culture in SM, we used the JAM assay. We found $40 \%( \pm 12.9)$ and $43 \%$ $( \pm 6)$ of apoptotic cells after 24 hours and 48 hours, respectively, in SM (Figure 9). Furthermore, to demonstrate the role of the Fas receptor in the regulation of HC-11 SM-induced apoptosis, cells were treated with anti-FasL (NOK-1 mAb) at the beginning of the culture. By blocking Fas/FasL interaction the apoptotic effect of hormonal removal in HC-11 cells was decreased (Figure 9). The control Ab, IgG1 isotype control immunoglobulin (clone 107.3; PharMingen) had no effect.

Fas-induced apoptosis. Further confirmation that Fas expressed by mammary cells is active was demonstrated by in vitro experiments using SM media and the agonist anti-Fas mAb. Mammary epithelial cells (MCF-10A and HC-11) were treated with increasing concentrations of anti-Fas $\mathrm{mAb}$ for 24 hours, and the Fas-mediated apoptosis was determined by either JAM or MTT assay. Upregulation of Fas expression after treatment with SM media resulted in increased responsiveness toward Fasmediated apoptosis (Figure 10).
In conclusion, culture of either $\mathrm{HC}-11$ or MCF-10A cells in SM induced the rapid expression of Fas and FasL, which is followed by activation of caspase 3 and the induction of apoptosis in more than $40 \%$ of the cells. Furthermore, addition of DEVD-CHO (caspase inhibitor) protected mammary epithelial cells to the apoptotic effect of Fas Ab or SM (data not shown). DEVD-CHO is a pseudosubstrate that mimics the caspase-3 cleavage site and thus inhibits its protease activity.

\section{Discussion}

Mammary involution, which entails the physiological removal (apoptosis) of breast cells after lactation, is a fundamental process involved in normal development of the mammary gland and cancer prevention. In the present study we have characterized the expression of Fas and FasL during the normal mammary gland development and have shown a correlation between their expression and PCD of the involving mammary epithelium.

The normal development of mammary glands during pregnancy is characterized by a period of epithelial cell
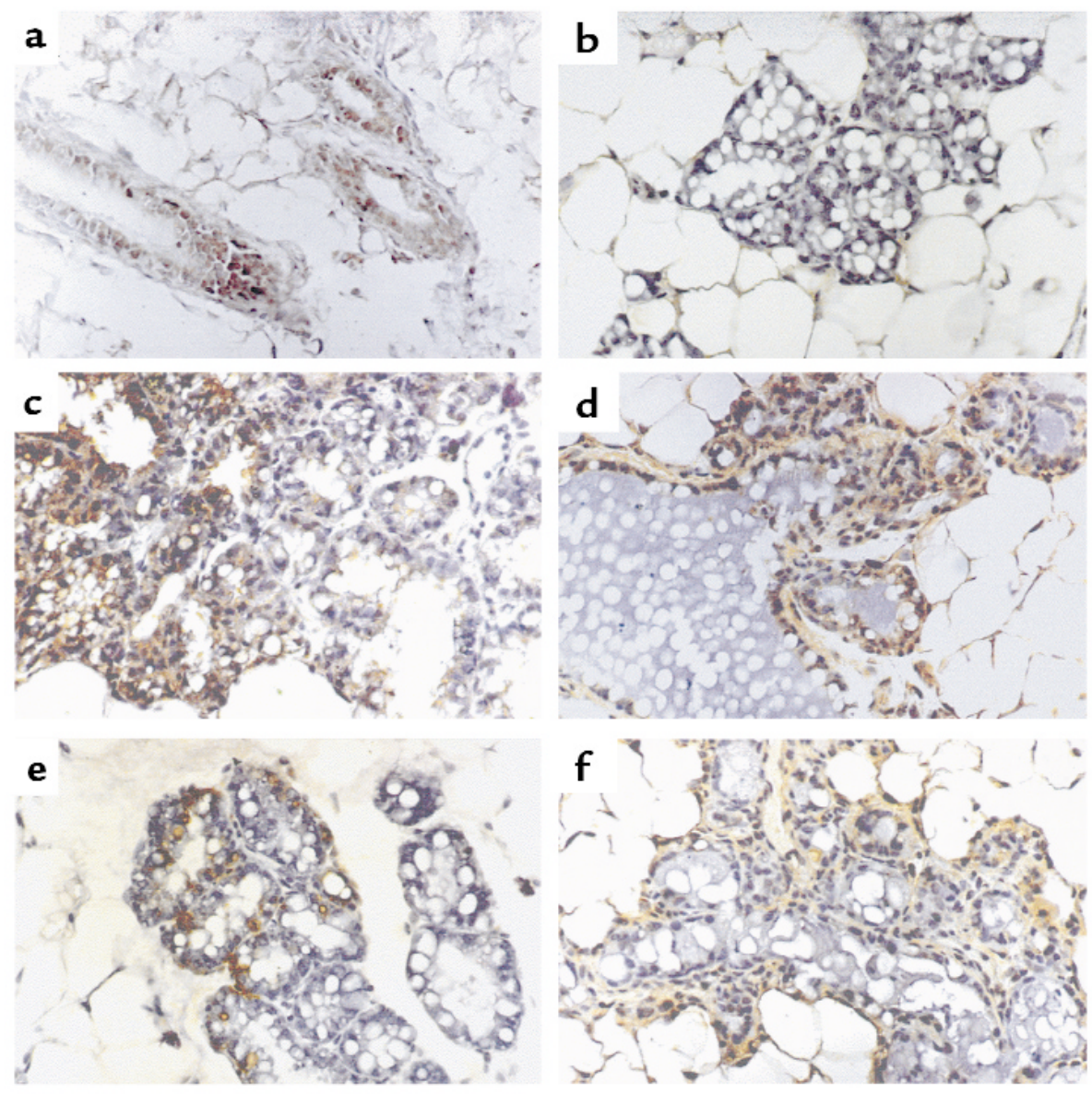

\section{Figure 5}

Localization of Fas expression in mouse mammary tissue during pregnancy, lactation, and involution. Immune staining of paraffin sections from mouse breast tissue is shown. (a) Virgin mouse breast, showing Fas-positive immune reactivity. (b) Day 15 of pregnancy, Fas-positive immune reactivity was absent except for some scattered positive stromal cells. (c) Day 1 of involution, strong Fas-positive immune reactivity was found in part of the glandular epithelium. (d) Day 2 of involution, the number of Fas-expressing cells is significantly increased. (e) Day 3 of involution. (f) Day 5 of involution, showing mainly ducts and epithelial chordae surrounded by adipocytes with localization of Fas in a few cells. $\times 400$. 

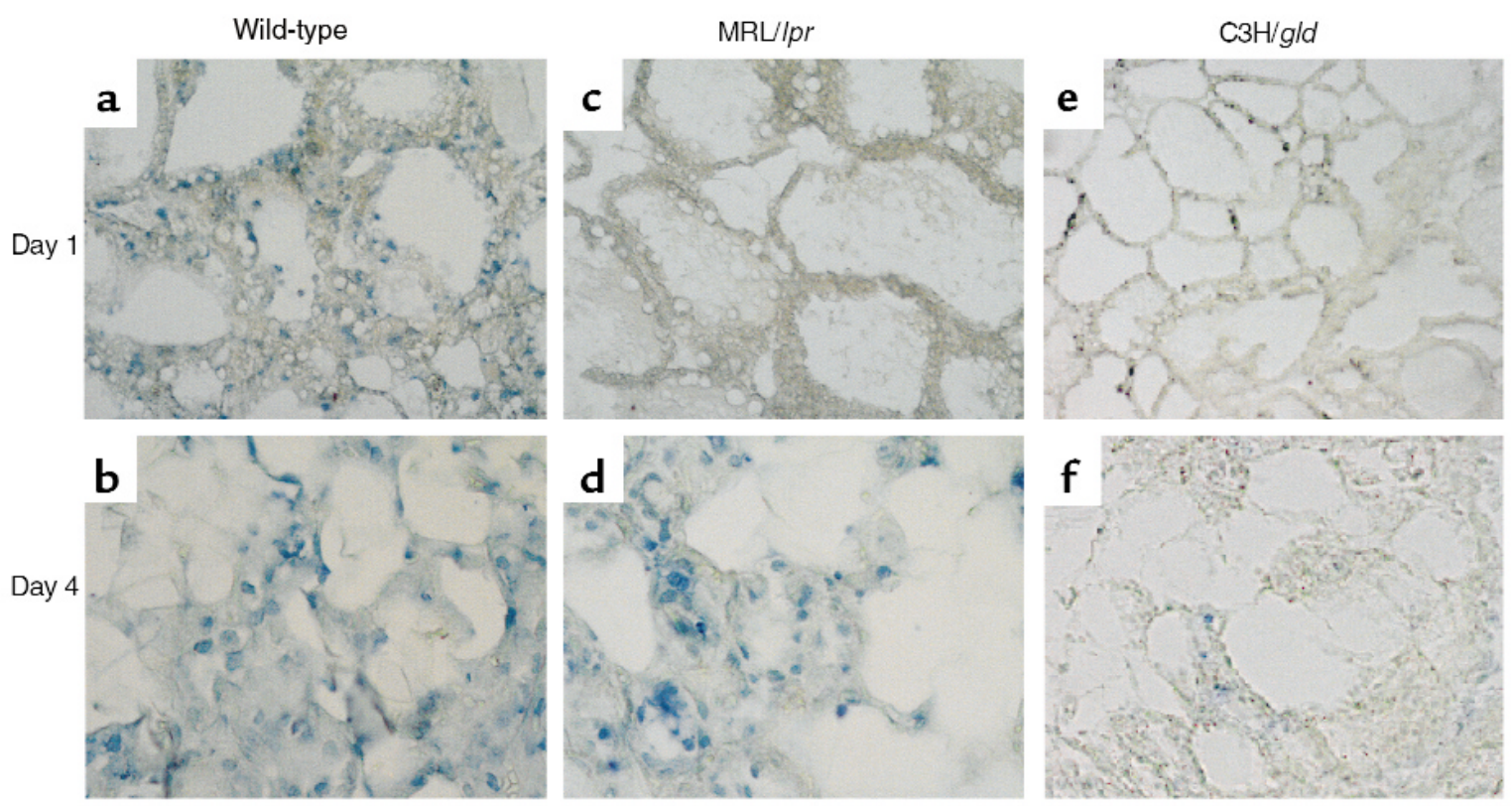

\section{Figure 6}

Localization of apoptosis in mouse mammary tissue during involution. Apoptosis in the involuting mammary gland was monitored by TUNEL on 5- $\mu \mathrm{m}$ paraffin sections derived from mammary glands of the MRL and $\mathrm{C} 3 \mathrm{H}$ mouse, the Fas-deficient MRL/Ipr mouse, and the FasL-deficient $\mathrm{C} 3 \mathrm{H} /$ gld mouse. (a) Wild-type MRL mouse, day 1 of involution, showing numerous apoptotic cells (positive nuclei are detected as blue spots) in glandular structure. (b) Wild-type MRL mouse, day 4 of involution; the number of apoptotic cells is significantly increased. (c) $\mathrm{MRL} /$ /pr mouse, day 1 of involution, showing no evidence of apoptosis on intact glandular structure. (d) MRL/lpr mouse, day 4 of involution, showing increased number of apoptotic cells. $\times 400$. (e) $\mathrm{C} 3 \mathrm{H} / \mathrm{g} / \mathrm{d}$ mouse, day 1 of involution, showing no evidence of apoptosis on intact glandular structure. $\times 200$. (f) $\mathrm{C} 3 \mathrm{H} /$ gld mouse, day 4 of involution, showing apoptotic cells. $\times 200$.

proliferation followed by the differentiation of milk-producing cells after parturition. Several investigators have suggested that this differentiation is terminal and commits the differentiated cells to undergo PCD (apoptosis). Walker and coworkers have demonstrated that in the mouse and rat, mammary tissue involution is accompanied by the cleavage of chromatin into oligonucleotide fragments (31), a characteristic of apoptosis (32-34). These and other studies $(35,36)$ provide strong evidence that cell loss during involution occurs by PCD. The occurrence of such remodeling is supported by experimental manipulations that have shown that after litter removal, lactation can be maintained and involution impeded by injection of hormones similar to those that we removed in our in vitro experiments $(37,38)$.

\section{Figure 7}

Expression of Fas/FasL and caspase 3 in mouse mammary glandular epithelial cell line HC-11. Western blot analysis for Fas (a) and FasL (b) was performed with protein extracted from in vitro culture of HC11 cells. Note the increase of Fas protein expression after 1 hour in hormone- and serum-deprived media (SM). FasL protein was expressed after 2 hours in SM and reached the highest level after 24 hours. (c) Western blotting for caspase 3 was performed with the same protein as above. Presence of SM converted the inactive form of caspase 3 to an active form corresponding to Fas and FasL expression. Lane 1, culture in normal media; lane 2, 1 hour in SM; lane 3, 2 hours in SM; lane 4, 6 hours in SM; lane 5, 24 hours in SM.
Apoptosis is influenced by a wide variety of stimuli. Among the known "death receptors" (TNF-R1, DR-3, TRAIL-R1 and -R2), Fas is one of the most important death-domain receptor. Interaction of Fas with its ligand, FasL, induces receptor trimerization, which in turn results in the recruitment of the adapter protein FADD and activation of caspases (39), which leads to irreversible cell damage and death (40).

In the present studies we demonstrate that although Fas protein is present during normal breast development, it is absent during pregnancy and lactation, only to return after weaning. Interestingly, Fas mRNA is present through the entire period. This phenomenon has been described in other cases and is referred to as "illegitimate transcription" (41-43). On the other hand, FasL

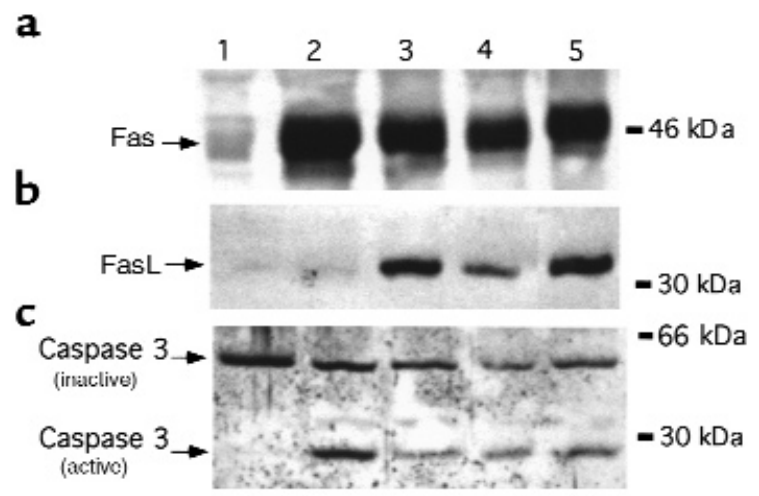



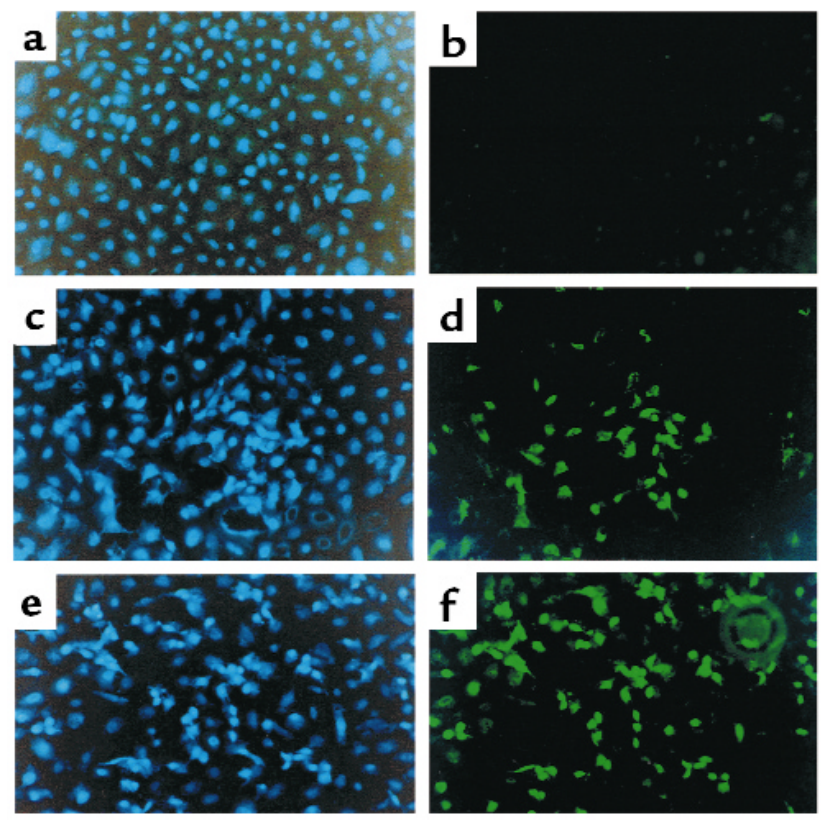

\section{Figure 8}

In situ detection of apoptotic cells in in vitro culture of mammary glandular epithelial cells. MCF-10A and HC-11 cells were treated with SM for 24 and 48 hours. Apoptotic cells were detected by annexin $\mathrm{V}(\mathbf{b}, \mathbf{d}, \mathbf{f})$. The figures are a representative experiment using $\mathrm{HC}$ 11 cells. (b) Annexin $V$ staining of cells in complete media. (d) After 24 hours in SM. (f) After 48 hours in SM. (a, c, e) DAPI staining was used to prove the presence of cells in $\mathbf{b}, \mathbf{d}$, and $\mathbf{f}$, respectively. $\times 400$.

protein is present during pregnancy, lactation, and weaning, but not in the virgin mouse (Figures 1-4). The overlapping expression of Fas and FasL during involution is accompanied by apoptosis of the mammary epithelium. Apoptosis was monitored using the TUNEL assay on paraffin sections derived from mammary glands, where we also studied Fas and FasL expression. Apoptotic cells were detected at day 1 after weaning, reaching a relative maximum at day 4 of involution (Figure 6 , a and $b$ ). The presence of apoptotic cells at as early as 24 hours of involution is in accordance with numerous studies showing cell death in the first 4 days of involution and tissue remodeling later on $(38,44)$.

We further evaluated the role of Fas and FasL in mammary gland remodeling using the Fas-deficient $\mathrm{MRL} / \mathrm{lpr}$ mice, in which the Fas gene is interrupted by an early transposable element and carries a point mutation in the death domain $(24,45)$. Lack of Fas or FasL expression in the $\mathrm{MRL} / \mathrm{lpr}$ and $\mathrm{C} 3 \mathrm{H} /$ gld mice, respectively, prevented apoptosis of mammary cells during the first 3 days of involution (Figure 6, c and e). However, apoptotic cells were found at day 4 of involution (Figure 6, d and f), suggesting that the Fas/FasL system may play an important role in early stage of involution. The timing of the differences in mammary apoptotic cells in the MRL/lpr and C3H/gld mice is crucial in light of the two-stage model of involution proposed by Lund and coworkers (46). The authors proposed that, postlactational involution of the mammary gland is char- acterized by two distinct phases. The first phase of involution is characterized by rapid induction of proapoptotic genes within the epithelium (days 1-4) $(46,47)$. This is the period when Fas and FasL are active based on the pattern of apoptotic cells found in the $\mathrm{MRL} / \mathrm{lpr}$ and $\mathrm{C} 3 \mathrm{H} / g l d$ mice (Figure 6). The second phase of involution is characterized by the induction of genes encoding proteases within stroma cells that result in the remodeling of the gland (46). This phase is Fas/FasL independent as shown by the presence of apoptotic cells in the MRL/lpr and $\mathrm{C} 3 \mathrm{H} /$ gld mice.

This chronology is consistent with Fas and FasL being expressed in the cell surface during the first phase, resulting in the "suicide" of the secretory epithelium. Cells escaping the first phase are then removed by secondary mechanism that is Fas independent. At this time, stroma cells, including macrophages, may induce cells death of the epithelium to ensure the removal of secretory cells (48). IL-1 $\beta$-converting enzyme (ICE) and p53, two important apoptotic genes, have also been shown to be expressed during the first phase $(23,46$, 49). It is noteworthy that these two genes are related to the mechanism of action by which Fas induces apoptosis in normal cells (50-54).

Cells undergoing neoplastic transformation are characterized by the complete or partial loss of posttranslational Fas expression, which leads to resistance to Fas/FasL-induced apoptosis (55-57). While Fas resistance has been reported in breast carcinoma cell lines (58), until now the normal physiological regulation of Fas in breast tissue was unknown. In the present study, we show for the first time that the molecular regulation of Fas and FasL in the mammary gland is sensitive to the hormonal microenvironment, with the expression of Fas and FasL varying according to the stage of development. Thus, during pregnancy, a time of high levels of estrogen and progesterone and very active mammary epithelial cell proliferation, Fas expression is inhibited while FasL protein levels are increased (Figure 2).

Stimulation of mammary cells with sex hormones or lactogenic hormones normally result in cell growth and differentiation (59). These hormones also synergize to promote cell survival by enhancing the production of growth factors and cytokines and the upregulation of antiapoptotic cellular proteins. Although estrogen has been proven to be a hormone that promotes cell survival, stimulation of mammary cells through the estrogen receptor leads to increased cell-surface expression of FasL, an apoptotic gene (27). This estrogenic effect demonstrates that during cell growth and differentiation there is a tight connection between signaling pathways that support cell survival and those that culminate in apoptosis.

We further characterized those cells that express Fas and FasL using immunocytochemistry. Positive immunoreactivity was localized primarily in the glandular epithelium. Moreover, we found not only changes in levels of expression, but also in the intracellular distribution; for example, during pregnancy FasL staining 


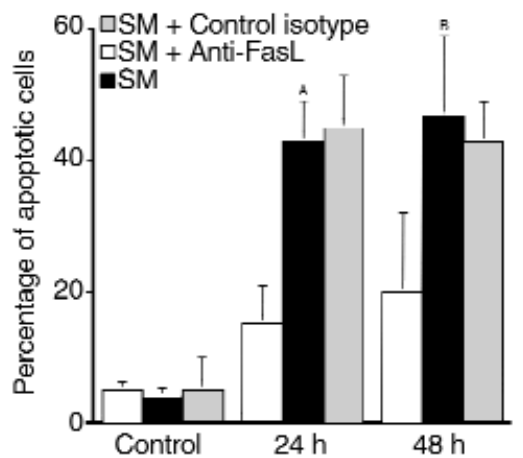

\section{Figure 9}

Fas dependence of SM-induced apoptosis. Mammary glandular epithelial cells MCF-10A (human) and HC-11 (mouse) were labeled with $\left[{ }^{3} \mathrm{H}\right]$-thymidine for 24 hours and treated with SM for 24 hours and 48 hours in the presence or absence of anti-FasL (NOK-1 mAb, $100 \mathrm{ng} / \mathrm{ml}$ ). As control we used the purified mouse IgG1 isotype control from PharMingen. The percentage of apoptosis was calculated as described in the text. Data represent the mean \pm SD of three independent experiments. ${ }^{A} P<0.001,{ }^{\mathrm{B}} P<0.05$.

was predominantly in the cytoplasm, while during involution both Fas and FasL had a primarily membranous localization. The immunostaining for Fas and FasL was not homogeneous, even in the same gland or duct (Figures 4 and 5). Some cells were positively stained, while other nearby cells were stained negatively, suggesting differences in remodeling stages between cellular districts of the glands and ducts. This heterogeneity seems to be related to differences in remodeling stages between cellular districts of the glands and ducts. Moreover, this heterogeneity of apoptosis (milk shut-down) provides a survival advantage since the entire function of the gland is not lost immediately when sucking stops. Rather, apoptotic factors (e.g., Fas/FasL) trigger graded PCD and decreased milk production, allowing for sucking to be restarted if necessary. If pups resume suckling, the hormonal microenvironment, which constitutes a survival factor, inhibits apoptosis and promotes restoration of milk production. However, if suckling is not restored, the second phase of involution takes place, promoting disruption of basement membrane and extracellular matrix, resulting in a complete remodeling of the gland to a state resembling the mature virgin (47).

To verify the role of Fas and FasL in postlactational involution, we designed an in vitro system employing the normal human MCF-10 cells and the mouse epithelial cells HC-11. HC-11 is an excellent model to study lactogenic differentiation and involution since these cells retain important features of normal mammary epithelial cells as evidenced by their ability to differentiate and synthesize the milk protein $\beta$-casein after exposure to lactogenic hormones (60). Removal of lactogenic hormones from these mammary epithelial cells induces the expression of Fas and FasL, followed by caspase 3 activation and cellular cell death (Figures 7 and 8). Quantification of cell death using the JAM assay showed that $40 \%$ of the cells were apoptotic after 24 hours of treatment (Figure 9) corresponding to the levels of Fas and FasL expression. The expression of these two proteins had a time pattern similar to the presence of apoptotic cells determined by an annexin $V$ and JAM assay (Figure 8 and 9). Hence, both assays demonstrate a correlation between the presence of apoptotic cells and the expression of Fas and FasL. Furthermore, the activation of caspase 3 after SM treatment (Figure 7), the induction of apoptosis with antiFas $\mathrm{mAb}$ (Figure 10), and the partial blocking of apoptosis with anti-FasL mAb (Figure 9) further suggest the involvement of Fas and FasL as the mediator of apoptosis in mammary epithelium.

The expression of Fas and FasL during the involution of breast tissue, as well as the presence of apoptotic cells, further supports our hypothesis that the regulation of cell proliferation and cell death by the Fas/FasL system is not confined to cells of the immune system $(26,61)$. In immune as well as in nonimmune cells numerous evidence suggests that the Fas/FasL system operates downstream of other cellular control mechanisms, such as p-53 (50), c-Myc (54), or Ras (52), to protect against neoplastic transformation $(20,62,63)$. Specifically, the death of mammary epithelium during the period of involution may be a physiologic means of eliminating mutated or otherwise transformed cells.

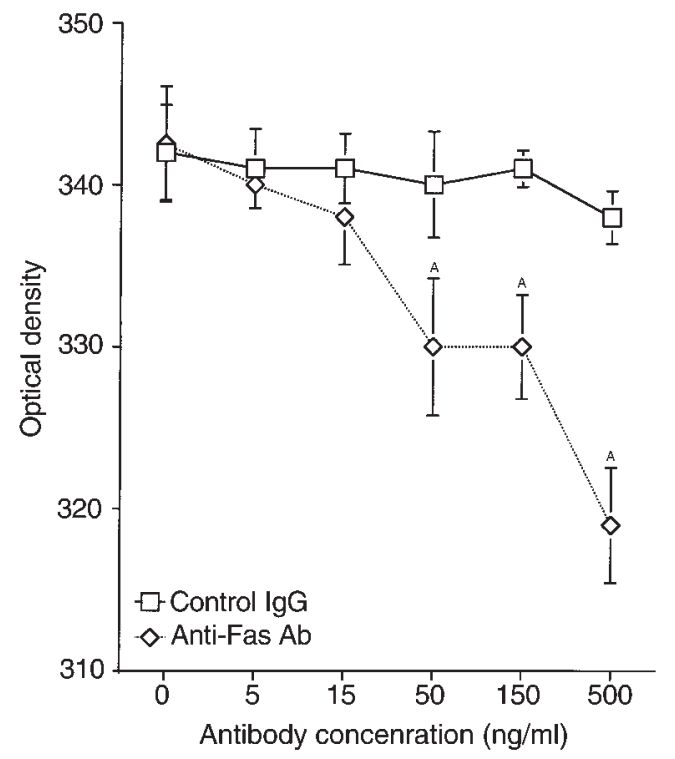

Figure 10

Effects of the anti-Fas mAb on HC-11 and MCF-10A cells. Normal mammary glandular epithelial cells MCF-10A and HC-11 were cultured with different concentrations of anti-Fas IgG mAb for 24 hours (ranging from $5-500 \mathrm{ng} / \mathrm{ml}$ ). MTT assay was performed to evaluate cell viability. As control, cells were treated with a mouse IgG1 mAb at concentrations similar to the anti-Fas $A b .{ }^{A} P<0.05$. Results shown are representative of at least three independent experiments done with $\mathrm{HC}-11$ cells. 
Weaning after breast feeding, which constitutes a crucial factor for involution in the mammary gland, significantly increases Fas protein expression and mammary epithelium apoptosis.

In conclusion, the present study further links the Fas/FasL system and hormones such as estrogen and lactogenic hormones to the biology of the normal mammary gland and the development of breast cancer. We have shown previously how estrogen regulates FasL expression in breast cancer cells to produce an immunologically privileged site that allows the progression of breast cancer without rejection (27). Supporting this hypothesis, we showed that the estrogen receptor antagonist tamoxifen blocks the expression of FasL, which may help to explain it's beneficial role in preventing or treating breast cancer (27). The present report extends our studies to the prevention of breast cancer, suggesting that breast remodeling after lactation could be mediated also by the Fas/FasL system and may play a physiological role in eliminating potentially cancerous cells of the mammary epithelium.

\section{Acknowledgments}

This work has been supported in part by a grant from the Department of the Army (DAMD17-98-1-8359 to G. Mor); a grant from Patrick and Catherine Weldon Donaghue Medical Research Foundation (to E. Sapi); grants from the NIH (R01HD-37137 to G. Mor, CA47292 to B.M. Kacinski, and AR-40072 and AR-44076 to J. Craft); and a grant from the American Cancer Society (ADT-66 to B.M. Kacinski). G. Mor, F. Naftolin, E. Sapi, J. Craft, and B.M. Kacinski are members of the Yale Cancer Center.

1. Edwertz, M., et al. 1990. Age at first birth, parity and risk of breast cancer: a metaanalysis of 8 studies from Nordic countries. Int. J. Cancer. 46:597-603.

2. Harris, J., Lippman, M., Veronesi, U., and Willet, W. 1992. Breast cancer. N. Engl. J. Med. 327:319-328.

3. Yang, C., et al. 1993. History of lactation and breast cancer risk. Am.J. Epidemiol. 136:1050-1056.

4. Hadsell, D.L., Greenberg, N.M., Fligger, J.M., Baumrucker, C.R., and Rosen, J.M. 1996. Targeted expression of des(1-3) human insulin-like growth factor I in transgenic mice influences mammary gland development and IGF-binding protein expression. Endocrinology. 137:321-330.

5. Jager, R., Herzer, U., Schenkel, J., and Weiher, H. 1997. Overexpression of $\mathrm{Bcl}-2$ inhibits alveolar cell apoptosis during involution and accelerates c-myc-induced tumorigenesis of the mammary gland in transgenic mice. Oncogene. 15:1787-1795.

6. Sandgren, E.P., et al. 1995. Inhibition of mammary gland involution is associated with transforming growth factor alpha but not c-mycinduced tumorigenesis in transgenic mice. Cancer Res. 55:3915-3927.

7. Yagita, M., Seppo, A., Renkonen, O., and Saksela, E. 1993. Deacetylase activity of human tumor cells producing immunosuppressive aminosugars: its possible role in resistance to cell-mediated cytotoxicity. Cancer Res. 53:5600-5604

8. Bergelson, L. 1993. Gangliosides and antitumor immunity. Clin Investig. 71:590-594.

9. Gabathuler, R., Reid, G., Kolaitis, G., Driscoll, J., and Jefferies, W. 1994. Comparison of cell lines deficient in antigen presentation reveals a functional role for TAP-1 alone in antigen processing. J. Exp. Med. 180:1415-1420.

10. Itoh, N., et al. 1991. The polypeptide encoded by the cDNA for human cell surface antigen Fas can mediate apoptosis. Cell. 66:233-243.

11. Suda, T., Takahashi, T., Golstein, P., and Nagata, S. 1993. Molecular cloning and expression of the Fas ligand, a novel member of the tumor necrosis factor family. Cell. 75:1169-1178.

12. Bellgrau, D., et al. 1995. A role for CD95 ligand in preventing graft rejection. Science. 377:630-632.
13. Griffith, T., Brunner, T., Fletcher, S., Gree, D., and Ferguson, T. 1995. Fas ligand induced apoptosis as a mechanism of immune privilege. Science. 270:1189-1192.

14. Bamberger, A., et al. 1997. Expression of the apoptosis-inducing Fas ligand (FasL) in human first and third trimester placenta and choriocarcinoma cells. J. Clin. Endocrinol. Metab. 82:3173-3175.

15. Guller, S., and LaChapelle, L. 1999. The role of placental Fas ligand in maintaining immune privilege at maternal-fetal interfaces. Semin. Reprod. Endocrinol. 17:39-44.

16. Mor, G., Gutierrez, L., Eliza, M., Kahyaoglu, F., and Arici, A. 1998. FasFas ligand system induced apoptosis in human placenta and gestational trophoblastic disease. Am. J. Reprod. Immunol. 40:89-95.

17. Bechmann, I., et al. 1999. FasL (CD95L, Apo1L) is expressed in the normal rat and human brain-evidence for the existence of an immunological brain barrier. Glia. 27:62-74.

18. Gutierrez, L., Eliza, M., Niven-Fairchild, T., Naftolin, F., and Mor, G. 1999. The Fas/Fas-ligand system: a mechanism for immune evasion in human breast carcinomas. Breast Cancer Res. Treat. 5:245-253.

19. Niehans, G.A., et al. 1997. Human lung carcinomas express Fas ligand. Cancer Res. 57:1007-1012.

20. Ben-Hur, H., et al. 1999. Apoptosis and apoptosis-related proteins in the epithelium of human ovarian tumors: immunohistochemical and morphometric studies. Eur. J. Gynaecol. Oncol. 20:249-253.

21. Villunger, A., et al. 1997. Constitutive expression of Fas (Apo-1/Cd95) ligand on multiple myeloma cells: a potential mechanism of tumorinduced suppression of immune surveillance. Blood. 90:12-20.

22. Dickson, R., and Lippman, M. 1995. Growth factors in breast cancer. Endocr. Rev. 16:559-589.

23. Jerry, D.J., Pinkas, J., Kuperwasser, C., Dickinson, E.S., and Naber, S.P. 1999. Regulation of p53 and its targets during involution of the mammary gland. J. Mammary Gland Biol. Neoplasia. 4:177-181.

24. Adachi, M., et al. 1995. Targeted mutation in the Fas gene causes hyperplasia in peripheral lymphoid organs and liver. Nat. Genet. 11:294-300.

25. Takahashi, T., et al. 1994. Generalized lymphoproliferative disease in mice, caused by point mutation in the Fas ligand. Cell. 76:969-976.

26. Garcia-Velasco, J., Arici, A., Naftolin, F., Zreick, T., and Mor, G. 1998. Macrophage-derived growth factors regulate FasL expression in endometrial stromal cells. Mol. Hum. Reprod. 5:642-650.

27. Mor, G., et al. 2000. Regulation of Fas ligand expression in breast cancer cells by estrogen: functional differences between estradiol and tamoxifen. J. Steroid Biochem. Mol. Biol. 73:184-194.

28. Strand, S., et al. 1996. Lymphocyte apoptosis induced by CD95 (APO-1 Fas) ligand-expressing tumor cells - a mechanism of immune evasion? Nat. Med. 2:1361-1366.

29. Matzinger, P. 1991. The JAM test. J. Immunol. Methods. 145:185-192.

30. Sapi, E., Flick, M., Rodov, S., Carter, D., and Kacinski, B. 1998. Expression of CSF-1 and CSF-1 receptor by normal lactating mammary epithelial cells. J. Soc. Gynecol. Invest. 5:94-101.

31. Walker, N.I., Bennett, R.E., and Kerr, J.F. 1989. Cell death by apoptosis during involution of the lactating breast in mice and rats. Am. J. Anat. 185:19-32.

32. Morris, R.G., Hargreaves, A.D., Duvall, E., and Wyllie, A.H. 1984. Hormone-induced cell death. 2. Surface changes in thymocytes undergoing apoptosis. Am. J. Pathol. 115:426-436.

33. Duvall, E., Wyllie, A.H., and Morris, R.G. 1985. Macrophage recognition of cells undergoing programmed cell death. Immunology. 56:351-358.

34. Kerr, J.F., Wyllie, A.H., and Currie, A.R. 1972. Apoptosis: a basic biological phenomenon with wide-ranging implications in tissue kinetics. $B r$. J. Cancer. 26:239-257.

35. Quarrie, L.H., Addey, C.V., and Wilde, C.J. 1995. Apoptosis in lactating and involuting mouse mammary tissue demonstrated by nick-end DNA labelling. Cell Tissue Res. 281:413-419.

36. Quarrie, L.H., Addey, C.V., and Wilde, C.J. 1996. Programmed cell death during mammary tissue involution induced by weaning, litter removal, and milk stasis. J. Cell. Physiol. 168:559-569.

37. Ossowski, L., Biegel, D., and Reich, E. 1979. Mammary plasminogen activator: correlation with involution, hormonal modulation and comparison between normal and neoplastic tissue. Cell. 16:929-940.

38. Strange, R., et al. 1995. Programmed cell death during mammary gland involution. Methods Cell Biol. 46:355-368.

39. Nagata, S. 1994. Fas and Fas ligand: a death factor and its receptor. Adv. Immunol. 57:129-135.

40. Nagata, S., and Golstein, P. 1995. The Fas death factor. Science. 267:1449-1456.

41. Kaplan, J.C., Kahn, A., and Chelly, J. 1992. Illegitimate transcription: its use in the study of inherited disease. Hum. Mutat. 1:357-360.

42. Chelly, J., et al. 1991. Illegitimate transcription. Application to the analysis of truncated transcripts of the dystrophin gene in nonmuscle cultured cells from Duchenne and Becker patients. J. Clin. Invest. 88:1161-1166.

43. Chelly, J., Concordet, J.P., Kaplan, J.C., and Kahn, A. 1989. Illegitimate transcription: transcription of any gene in any cell type. Proc. Natl. Acad. Sci. USA. 86:2617-2621. 
44. Strange, R., Li, F., Saurer, S., Burkhardt, A., and Friis, R. 1992. Apoptotic cell death and tissue remodeling during mouse mammary gland involution. Development. 115:49-58.

45. Adachi, M., Watanabe-Fukunaga, R., and Nagata, S. 1993. Aberrant transcription caused by the insertion of an early transposable element in an intron of the Fas antigen gene of $l p r$ mice. Proc. Natl. Acad. Sci. USA. 90:1756-1760.

46. Lund, L.R., et al. 1996. Two distinct phases of apoptosis in mammary gland involution: proteinase-independent and -dependent pathways. Development. 122:181-193.

47. Li, M., et al. 1997. Mammary-derived signals activate programmed cell death during the first stage of mammary gland involution. Proc. Natl. Acad. Sci. USA. 94:3425-3430.

48. Furth, P.A. 1999. Introduction: mammary gland involution and apoptosis of mammary epithelial cells. J. Mammary Gland Biol. Neoplasia. 4:123-127.

49. Boudreau, N., Sympson, C.J., Werb, Z., and Bissell, M.J. 1995. Suppression of ICE and apoptosis in mammary epithelial cells by extracellular matrix. Science. 267:891-893.

50. Fuchs, E., McKenna, K., and Bedi, A. 1997. P53-dependent DNA damage-induced apoptosis requires Fas/Apo-1-independent activation of Cpp32-beta. Cancer Res. 57:2550-2554.

51. Sloand, E.M., Young, N.S., Sato, T., Kim, S., and Maciejewski, J.P. 1998. Inhibition of interleukin-1beta-converting enzyme in human hematopoietic progenitor cells results in blockade of cytokine-mediated apoptosis and expansion of their proliferative potential. Exp. Hematol. 26:1093-1099.

52. Muller, M., et al. 1998. p53 activates the CD95 (APO-1/Fas) gene in response to DNA damage by anticancer drugs. J. Exp. Med. 188:2033-2045.
53. Muller, M., et al. 1997. Drug-induced apoptosis in hepatoma cells is mediated by the CD95 (APO-1/Fas) receptor/ligand system and involves activation of wild-type p53. J. Clin. Invest. 99:403-413.

54. Bennett, M., et al. 1998. Cell surface trafficking of Fas: a rapid mechanism of p53-mediated apoptosis. Science. 282:290-293.

55. Moller, P., Walczak, H., Reidl, S., Strater, J., and Krammer, P.H. 1996. Paneth cells express high levels of CD95 ligand transcripts: a unique property among gastrointestinal epithelia. Am. J. Pathol. 149:9-13.

56. Lebel, M., Bertrand, R., and Mes-Masson, A.M. 1996. Decreased Fas antigen receptor expression in testicular tumor cell lines derived from polyomavirus large T-antigen transgenic mice. Oncogene. 12:1127-1135.

57. Hahne, M., et al. 1996. Melanoma cell expression of Fas(Apo-1/CD95) ligand: implications for tumor immune escape. Science. 274:1363-1366.

58. Keane, M.M., Ettenberg, S.A., Lowrey, G.A., Russell, E.K., and Lipkowitz, S. 1996. Fas expression and function in normal and malignant breast cell lines. Cancer Res. 56:4791-4798.

59. Russo, J., et al. 1998. Biological and molecular basis of human breast cancer. Front. Biosci. 3:D944-D960.

60. Sapi, E., and Kacinski, B.M. 1999. The role of CSF-1 in normal and neoplastic breast physiology. Proc. Soc. Exp. Biol. Med. 220:1-8.

61. Quirk, S.M., Cowan, R.G., and Huber, S.H. 1997. Fas antigen-mediated apoptosis of ovarian surface epithelial cells. Endocrinology. 138:4558-4566.

62. Ben-Hur, H., et al. 2000. Apoptosis and apoptosis-related proteins (Fas, Fas ligand, bcl-2, p53) in macrophages of human ovarian epithelial tumors. Eur. J. Gynaecol. Oncol. 21:141-145.

63. Ben-Hur, H., et al. 2000. Apoptosis and apoptosis-related proteins (Fas, Fas ligand, Blc-2, p53) in lymphoid elements of human ovarian tumors. Eur. J. Gynaecol. Oncol. 21:53-57. 